UDC 141.9

\author{
A. M. MALIVSKYI ${ }^{1 *}$ \\ ${ }^{1 *}$ Dnipro National University of Railway Transport named after Academician V. Lazaryan (Dnipro, Ukraine), \\ e-mail telepat-57@ukr.net, ORCID 0000-0002-6923-5145
}

\title{
DOCTRINE OF MAN IN DESCARTES AND PASCAL
}

Purpose. The paper aims at substantiating the meaningful relationship between Descartes' and Pascal's positions as two variants in responding to the demand of the era in the development of anthropology. The realization of this purpose involves defining the spiritual climate of the era and addressing to the texts of two great French thinkers of the 17th century to demonstrate common moments in interpreting the phenomenon of a man. Theoretical basis. The methodological basis in the research is the conceptual propositions of the representatives of phenomenology and hermeneutics. Originality. The existence of the doctrine of human nature by Descartes is argued and the manifestations of common moments with Pascal's doctrine are outlined. The latter include the context of the Copernican unfinished Revolution, the emphasis on restrictions in the methodology of the natural sciences, the intense search for description language beyond the rational components of human nature, the high opinion in the Christian understanding of man, critique of atheism. Conclusions. The paper substantiates the meaningful relationship in the doctrine of man from both French thinkers, which manifests itself in the vision of the initial situation as a person's choice of their own foundations in the course of conceptualization the scientific revolution, understanding of Christianity as a basic paradigm of thinking, priority of the anthropological interest over natural-science one, the dominant role of the ethical philosophizing motive.

Keywords: Descartes; Pascal; man; anthropology; religion; rationality; scientific revolution; ethics

\section{Introduction}

Among those obsolete common stereotypes regarding man, there is an idea concerning the opposite and incompatibility in the doctrines of Rene Descartes and Blaise Pascal. Analysing the factors of their development one testifies to the widespread idea about the essential difference of the basic attitudes of their creativity. In the first case, we are talking about the direct influence of the scientific revolution, in the second it is about anthropologism. At the same time, the meaningful relationship in the positions of two great French thinkers of the 17th century remains unnoticed. Therefore, it is advisable to emphasize Descartes' conscious efforts to conceal his true intentions, defined in the text of "Early Writings" (Malivskyi, 2018).

Addressing the pages of the research literature, we see that interest in common moments in the heritage of two great French thinkers of the 17th century has always existed. Some authors focus on the peculiarities of natural-science interests in their brilliant heritage (Ariew, 2007), others emphasize differences in interpretation of epistemology (Franchetti, 2012), still, others astutely observe the substantive continuity with Renaissance humanism; fourths analyze Pascal's point of view through the prism of his era (Hammond, 2003). Profound, though debatable is the author's position, which associates ethics of thought only with Pascal's position (Hibbs, 2005). The original attempt to emphasize the distinctiveness of the modern reception of two French geniuses from the seventeenth-century using a biographical method belongs to Professor O. Khoma (2012). However, the stereotype regarding the reduced position of Descartes and the linkage of interest to man only with Pascal's creativity are still without due attention. An essential circumstance is also ignored, that from the standpoint of modern science Pascal is interesting not so much for criticizing Descartes's doctrine as for his own vision in the demand of the Early Age for anthropology. Based on the foregoing, it is appropriate to substantiate the meaningful rela- 
tionship between the positions of Descartes and Pascal as two variants for responding to the demand of the era regarding a holistic vision of man. Since until now it was generally accepted that the prerequisite for comprehending Pascal's outstanding ideas is attention to Descartes' constructive rethinking by him as an embodiment of his own era, then I think it is fair to slightly shift the emphasis. In my opinion, the analysis of the question of Pascal's attitude to the anthropological dimension of the Cartesian philosophy now comes to the fore. Significant obstacles to understanding the problem of this article are, firstly, the unfinished nature of Descartes' doctrine and secretiveness of his true motives behind the mask of a natural scientist; secondly, the neglect of the anthropological-ethical aspect of his doctrine (Malivskyi, 2017), thirdly, insufficient coherence in the position of Pascal himself, which is accessible to us as separate fragments from the unwritten work "Apology of Religion".

\section{Purpose}

Based on the foregoing, the purpose of this article is to argue the meaningful relationship between Descartes and Pascal's positions as two variants in responding to the demand of the era in the development of anthropology. Its realization involves defining the spiritual climate of the era and addressing to the texts of two great French thinkers of the 17th century to demonstrate common moments in interpreting the phenomenon of man. The methodological basis in the research is the conceptual provisions of the representatives of phenomenology and hermeneutics.

\section{Statement of basic materials}

Axiomatically, the contemporary reception of peculiarities in human understanding in the Descartes and Pascal epochs must take into account the key influence of the scientific revolution, a manifestation of which is to emphasize the attributive nature of thinking for a person. And since Descartes' point of view on this issue is well-known, it is worth drawing attention to one of Pascal's aphorisms: "I can well conceive a man without hands, feet, head (for it is only experience which teaches us that the head is more necessary than feet). But I cannot conceive a man without thought. He would be a stone or a brute" (Pascal, 2009, p. 42). The attributive nature of thinking for him is axiomatic.

For us, the most important manifestation in the determinant influence of the scientific revolution on the position of both thinkers is the search for a way to solve the problem of the proper foundations of human existence. Also, their common starting point is the Christian vision of the human problem, as both see the realization of their own project in addressing the concepts of God and the immortal soul.

Since one of the significant obstacles to Descartes' philosophical heritage is the thesis of his absolutization of human thinking, its deconstruction is advisable. The results of his meditations on the problem of the proper foundations of human being are put into writing in "Meditations" text, where the subject of philosophy is defined as proving the existence of God and the immortality of the soul. The prerequisite for an authentic understanding of this approach is attention to the demand of the Early Age era for self-development. It is about the reception of the initial situation as a dilemma and the need for each person to choose their own priorities. As it evidenced by in-depth biographical studies, an essential feature of Descartes' personality is the sincerity of his religious beliefs as an orthodox Catholic. Nowadays, a generalized image of the thinker, who neglects the peculiarities of his position at each stage of his creative career, goes into the past (Khoma, 2012). The thesis about "Discourse on the Method" text as the embodiment of reduced 
rationalism, which is supplemented by temporary ethics and medicine (as a form of morality), is losing its conviction. For contemporary scholars, the ethics for Descartes in "Discourse" is more than an external facade (Wienand, 2009, p. 107). As for the following works ("Meditations on the First Philosophy" and "Passions of the Soul"), their basic intention is to find ways of selfrealization.

The meaningful discovery of the main points in Cartesian's position in the context of the unfinished scientific revolution implies a) going beyond perceptions about the self-sufficiency of human thinking and b) reflection concerning the way of the meaningful contingence of human nature with the image of God as the embodiment of perfection. Representative in this regard is the last words of the "Meditations", which emphasize the constitutive nature of the human presence in the form of a reference to the "infirmity and weakness of our nature" (Descartes, 1996, AT VII: 90) for the proof of the existence of God. We are talking about a meaningful continuation of the tradition rooted in the medieval period to interpret human weakness as an essential factor in the mentioned evidence.

In the course of the current refutation of established stereotypes regarding the absolutization of thinking in Descartes, one should pay attention to his interpretation of the existential status of man as man's middle position in the world: "I am, as it were, something intermediate between God and nothingness, or between the supreme being and non-being" (Descartes, 1996, AT VII: 54). Therefore, a person, as the embodiment of a split in being, is forced to choose himself, his proper image. In this case, the prerequisite and guarantor of true knowledge for Cartesian is God as the embodiment of positivity. Defining the subject of philosophy as proving the existence of God and the immortality of the soul, he sees it as the cornerstone on which metaphysics and ethics are built.

Analysing the basic character in the notion of freedom of both French thinkers, it is reasonable to draw attention to the fact of the inner affinity in their positions as a reflection of the era. In particular, it is about the central character for the situation of existential choice in determining the subject of philosophy in Pascal. He keenly felt the entire precariousness of human existence and the constant threat to him of nothingness. It is nothingness and "Nothing" as one of its synonyms in the XX century is perceived as the ultimate foundation of European culture, and human existence is accordingly characterized as a union of man with Nothing (Sartre and Heidegger accentuated this). The fateful significance of the Cartesian idea of nothingness for understanding the contemporary world in the XX century was accented by José Ortega-y-Gasset (1991), who rightly points out that "thinking about the secret power taken by our deception is Descartes' "evil spirit" is a profound and almost misunderstood idea" (p. 316).

Among the most famous manifestations of the determinative influence of the scientific revolution in the era of the Early Age is considered to be the thesis of the power of the human mind. Pascal, analysing the heritage of his elder countryman, rightly states the superficiality and danger of this stereotype. As a consequence, the main object of his criticism is Descartes' heritage as a visual illustration in the limitations of the natural-scientific form of mind, indifferent to the problems of morality, faith, God, the human calling in the universe.

For Pascal, as well as for his elder contemporary, the existential status of a person is that dramatic split in life that motivates him to clarify the boundaries and opportunities to independently influence one's own destiny. But his assessment of a person's initial position is much more pessimistic and tragic. Man is "between two abysses, infinity and nothing ... man in nature ... Nothing is against infinity, everything is against nothing, the middle between nothing and everything, in- 
finitely distant from the comprehending the edges..." (Pascal, 2009, p. 75). What are the possibilities of man through the mind to influence their own destiny?

For the contemporary reading in the positions of both human thinkers as outstanding natural scientists of their time, their interpretation of the boundaries for the theoretical reason is of the greatest interest. As the texts of thinkers convincingly testify, both are not inclined to overestimate a person's ability to be guided by mind and solve their problems through it. Descartes in "Meditations" emphasizes the ambiguity of the content in the concept of rationality, critically evaluating the definition of man as a rational being traditional for European culture since antiquity. According to the philosopher, it is impossible to agree with him now, because, he writes, I would have to ask again afterwards what a "living being" is and what is "endowed with reason" (Descartes, 1996, AT VII: 25). Pascal's assessment of the transformations nature in the rationality of human condition in the Early Age era is close substantive. At the same time, the latter draws attention to the paradoxical status of thinking in human nature:

Thought. All the dignity of man consists in thought. But what is this

thought? How foolish it is! The thought is therefore by its nature a won-

derful and incomparable thing. It must have strange defects to be con-

temptible. But it has such so that nothing is more ridiculous. How great it

is in its nature! How vile it is in its defects! (Pascal, 2009, p. 259)

Concretizing his own vision of the ambivalent position of man, Pascal argues the fallacy of the notions common in his time about the central status of man in the Universe. It is about the paradox of human nature, which is deprived of attention at the superficial reception. "What a chimera then is man! What a novelty! What a monster, what a chaos, what a contradiction, what a prodigy! Judge of all things, imbecile worm of the earth; depositary of truth, a sink of uncertainty and error; the pride and refuse of the universe!" (Pascal, 2009, p. 47). Is there any constructive way out of this situation?

As already mentioned, the forms of manifestation of the meaningful relationship in the positions of Descartes and Pascal include their interest in the deep connection of man with God. Paying tribute to the scientific revolution and thinking as the primary means of its development, Pascal, at the same time, connects with the mind of man his self-affirmation as a God-created being. In particular, he warns justifiably against the absolutization of reason and knowledge in their natural science form, since it threatens to destroy both the foundations of religion and human existence: "If we submit everything to reason, our religion will have no mysterious and supernatural element. If we offend the principles of reason, our religion will be absurd and ridiculous". The caveat cited is based on his own vision of the present stage of history, since, unfortunately, "this beautifully spoilt reason has ruined everything". Analysing the variants of a constructive way out of this tragic situation, he stresses the limitations of formal logic since there are "two extremes" are equally unacceptable for him, namely to "exclude the reason, accept only the reason" (Pascal, 2009).

Rightly seeing the essential flaws of natural knowledge in its orientation to external expression and indifference to the inner world of man, Pascal connects the method of overcoming them 
on the way to addressing the concepts of heart and faith. Perceiving Descartes' doctrine through the prism of the gnoseologization of philosophy, he tends to associate it with the wrongful extrapolation of the ideals of natural knowledge to the idea of God. Therefore, depersonalization of the latter seems undoubted, the manifestation of which is the famous thesis about God only as "God of scientists and philosophers".

Obviously, human nature for both Descartes and Pascal is not reduced to the rational component of human nature. Analysing methods of realizing the ideas of what is due in human nature, they both call for self-knowledge and self-realization. For Pascal, the fundamental impossibility of meaningful answers to the key ideological and philosophical questions is undoubted one: "I know neither the one who brought me into the world, nor what the world is, nor what I am, I live in a terrible nescience of everything; I do not know what my body is, my feelings, my soul, and even that part of me that thinks what I say, reflects everything and myself, and who knows himself no more than other things". The tragedy and hopelessness of human existence are linked both to the inability of a theoretical clarification of those issues that directly determine our vision of the proper foundations of human behavior and their practical implementation. A representative example is the problem of the immortal soul: "As I know not whence I come, so I know not whither I go. I know only that, in leaving this world, I fall for ever either into annihilation or into the hands of an angry God, without knowing to which of these two states I shall be for ever assigned" (Pascal, 2009, p. 146). Acknowledging the awfulness and inappropriateness of this state of affairs encourages Pascal to explicate those assumptions that make the calm and cloudless existence of his contemporaries.

As is commonly known, Descartes did not ignore a fact of the prevalence of carriers of "weak minds", but this fact did not cause him especial anxiety. Pascal, explaining and analysing the meanings and orientations of contemporary culture, is horrified and does not conceal his disappointment concerning the lifestyle of those of his contemporaries who are not inclined in the process of developing their own lives to appeal to reflection. Distancing himself from the carriers' position of naive and low-browed optimism, he writes: The fate of "those who live without comprehending... the ultimate goal of life" is absurd for him, because they live as if "it is possible to destroy eternity if you turn your mind away from it". Above all, the object of excitement and anxiety for the thinker is artificial calmness against the background of general ignorance. Pascal's sincerity to himself and his devotion to the truth cannot leave anyone indifferent today: "Whereas in my present state, ignorant of what I am or of what I ought to do, I know neither my condition nor my duty. My heart inclines wholly to know where is the true good, in order to follow it; nothing would be too dear to me for eternity" (Pascal, 2009, p. 150). In explaining the prerequisites for the carefree existence of ordinary people in the situation of the maximum dramatic position of man in the universe, Pascal focuses on the distortion of basic attitudes. It is about a person's inability to clarify the problem of proper principles, his inability to ascertain the problem of things in human nature, that is, and the "true state" of man. The most important hidden factors include "sensitivity to the smallest and strange insensitivity to the greatest". In other words, at the moment, human nature is "amazingly unstrung" for him (Pascal, 2009, p. 147). The necessary prerequisite for constructive overcoming the said deformation in human nature for Pascal is associated with the reflection of the "man-God" relationship. In refuting the position of atheists, he emphasizes, first of all, that a person is in himself incapable of knowing the world, because he "cannot even doubt". Strengthening his position, he points out that the given example is representative, because for him, "There is no more evidence of the weakness of the mind than 
not knowing what an unhappy man is without God" (Pascal, 2009, p. 148). Among the related deformations that must be eliminated there are illusory value systems. That is why a separate important point in the course of self-determination is to distance oneself from those who live in the world of their own fantasies: "I find it necessary to point out the sinfulness of those men who live in indifference to the search for truth in a matter which is so important to them, and which touches them so nearly". The consequences of re-evaluating the results of one's self-image are an artificial hierarchy of values, at the heart of which is the illusion of the true significance of things: "A man is vain because of the respect that he shows for insignificant things" (Pascal, 2009, p. 37).

Understanding the main factors of the deformation in the worldview of his own era, Pascal emphasizes the key role of the time reception method. For him, in particular, the fact of a distorted interpretation of Christianity, which is dominated by the attitude toward preparation for life, is unacceptable. According to it, his contemporaries not only live and enjoy real life but intensively prepare for the future happy life, neglecting modernity. The main factor of such deformation for him is caused by the unconscious fear of the present and the use of the possibility to hide from it in the past and in the future. Therefore, Pascal (2009) notes with unconcealed regret, "we almost never think about the present", it is "never our goal" (p. 24).

Despite the prevalence of superficial illusions regarding the priority of science over religion, analyzing ways of constructive overcoming the current decline, Pascal turns to Christianity as a symbolic milestone of self-knowledge himself by man. The only acceptable variant for the attitude towards Christianity, he emphasizes, is worship, because it is a religion "which knows so well the defects of man, and desire for the truth of a religion which promises remedies so desirable?" (Pascal, 2009, p. 226). Revealing the nature of the latter Pascal points to the self-interest of man, that is, his maximum interest in secular values far from those real Christian ones based on the understanding of human nature. In listing secular values, he emphasizes the priority of caring to look decent, loyal, prudent and able to serve a friend, because people, as a rule, love primarily what can be directly useful to them.

Paying tribute to the truth, it should be admitted that it is wrong to unambiguously link the thesis of the absolute priority of the scientific revolution and the associated secularization of world perception with the name of Descartes. Both he and Pascal note unanimously that naivety in world perception is a weak point in the position of the ungodly. According to Descartes, atheists do not pay enough attention to the fundamental difference between man and God: "... all the objections commonly tossed around by atheists to attack the existence of God invariably depend either on attributing human feeling to God or on arrogantly supposing our own minds..." (Descartes, 1996, AT VII: 9). Pascal's position is no less categorical, though more ironic: "Atheism shows the strength of mind, but only to a certain degree" (Pascal, 2009, p. 65). The latter connects the uniqueness of his attitude to modern philosophizing as the embodiment of the fragmentation of human nature with the need for a transition to its holistic comprehension, which involves turning to the heart. "We know the truth, not only through reason but also through the heart". Emphasizing the importance of a holistic view of the forms in man's knowledge of the world, he underlines that when it comes to "knowledge of the first principles", although we receive them through rational reasoning, we cannot but admit that, strictly speaking, we are talking about "knowledge of the heart and instinct" on which the rationale is based and discourse should be based too. Given the importance of a holistic vision of man for the development of the problem of the proper foundations in human behavior, Pascal warns against the temptation to expand 
natural science rationality that is, reducing the heart to knowledge. "The heart feels ... The principles are felt, the theorems are deduced" and therefore "it would be futile and ridiculous for the reason to demand from the heart evidence of its first principles ... as it would be ridiculous for the heart to demand from the reason the tangibility of all theorems..." (Pascal, 2009, p. 41).

The completeness of our familiarization with the variant of Pascal's answer to the demand of the era for the development of anthropology will be insufficient if we neglect that component of human nature, which he and his great contemporary calls the imagination. It is a "dominant component of man". As you know, Descartes also attributed imagination to those key components of human nature, the comprehension of which is a prerequisite for understanding the truth. First, for him, imagination is uniquely connected with material substance, and therefore, secondly, is a serious obstacle to self-knowledge. On the pages of "Meditations" we read: "... none of the things that the imagination enable me to grasp is at all relevant to this knowledge of myself which I possess, and that the mind must therefore be most carefully diverted from such thing if it is to perceive its own nature as distinctly as possible" (Descartes, 1996, AT VII: 28).

Pascal (like Descartes) links the essential deformations of human nature with the imagination, the main function is "a teacher of confusion and falseness, even slier by that he is not always sly..." By concretizing his own vision of the factors and obstacles in forming an objective picture of the world, Pascal focuses on the ability of the imagination. It is with it that he has significant fallacies in understanding, confirming his unconditional priority in the unannounced competition with the reason. Even among the "wisest... imagination gains a great right to convince people. In vain the reason calls out, it cannot be the price of things". Emphasizing the absolute dominance of the imagination in the established modes of reception of the world by man, Pascal justifiably considers it possible to qualify it as the "second nature" of man. "This arrogant power, the enemy of the reason ... It has established a second nature in man". According to Pascal, the key role of the image in the process of cognition is still underestimated, so for him, the loyalty to the reason proclaimed by scientists actually looks like smoke and a mirage. "Whoever wanted to follow only reason, he would be a complete fool by the conviction of the vast majority of secular people". Among the determining circumstances in the dominance of imagination the illusion of involvement with absolute meanings and the closely related illusory feeling of happiness hold pride of place. "Imagination cannot make fools wise, but it makes them happy ..." (Pascal, 2009, p. 19).

Summing up an excursion into own phenomenology of imagination, Pascal (2009) notes the falsity of naive ideas about the rationality of human nature, and the need to take into account its contradictory relationships with sensuality: "But the most powerful cause of error is the war existing between the senses and reason" (p. 22). On the pages of the "Meditations" of his senior contemporary, a contradiction emerges in the form of a confrontation between the sensual knowledge of the bodily things of nature and reason. "I apparently had natural impulse toward many things which reason told me to avoid ..." (Descartes,1996, AT VII: 77).

The logical consequence of recognizing a person's inability to comprehend rationally human nature in its present and proper dimensions for Pascal is the strong belief that man must find the courage in himself to acknowledge the groundlessness of expectations for a significant improvement in one's position in the universe through reason and optimism expectations connected with it. Therefore, turning to the mind and will, Pascal (2009) invokes: "Let us therefore not look for certainty and stability. Our reason is always deceived by fickle shadows; nothing can fix the finite between the two Infinites, which both enclose and fly from it" (p. 77). The only possible 
manner for human behavior is to admit courageously the inevitability and insurmountability of the tragic aspects and to stoically pass through them.

As the texts of two main French thinkers of Early Age attest, their position is united by the recognition of the key importance in a personal responsible attitude to life's realities.

\section{Originality}

The existence of the doctrine of human nature by Descartes is argued and the manifestations of common moments with Pascal's doctrine are outlined. The latter include the context of the unfinished Copernican Revolution, the emphasis on restrictions in the methodology of the natural sciences, the intense search for a description of language beyond the rational components of human nature, the high praise in the Christian understanding of man, critique of atheism.

\section{Conclusions}

Nowadays, the central place in the search for Descartes of anthropology is increasingly convincing for the historical and philosophical science. The author of the article substantiates the presence of meaningful related moments in the doctrines of Descartes and Pascal. The latter is connected with the general problem of their search for forms in responding to the demand of the era of anthropology as the foundation of a new worldview. Both are not inclined to absolutize the natural sciences and the inherent way of thinking, that is, to exaggerate the direct influence of the scientific revolution. According to the author's opinion, the meaningful relationship in the doctrine of a person of both French thinkers is manifested in the high opinion of the human reason, in the vision of the basic role of freedom, in understanding the initial situation as a choice, Christianity as a fundamental paradigm of thinking, and the dominance of ethical problems. The author links the perspectives of further research on the topic with the analysis of the texts of two thinkers as a meaningful dialogue regarding the major principles of morality; a humanistic directed reason is the core and based on Christian values.

\section{REFERENCES}

Ariew, R. (2007). Descartes and Pascal. Perspectives on Science,15(4), 397-409. doi: https://doi.org/10.1162/ posc.2007.15.4.397 (in English)

Descartes, R. (1996). Oeuvres completes: In 11 Vol. Paris: C. Adam et P. Tannery. (in French)

Franchetti, C. (2012). The Giants of Doubt: A Comparison between Epistemological Aspects of Descartes and Pascal. Open Journal of Philosophy, 2(3), 183-188. doi: https://doi.org/10.4236/ojpp.2012.23028 (in English)

Hammond, N. (Ed.). (2003). The Cambridge Companion to Pascal. Cambridge University Press. doi: https://doi.org/10.1017/ccol052180924x (in English)

Hibbs, T. (2005). Habits of the Heart: Pascal and the Ethics of Thought. International Philosophical Quarterly, 45(2), 203-220. doi: https://doi.org/10.5840/ipq20054522 (in English)

Khoma, O. (2012). Dekart i Paskal: Shliakh do filosofii na tli Grand Siècle. Philosophical Thought, 6, 19-38. (in Ukrainian)

Malivskyi, A. M. (2017). Anthropological project as a basis of Cartesian Ethics. Anthropological Measurements of Philosophical Research, 11, 117-126. doi: https://doi.org/10.15802/ampr.v0i11.105495 (in Ukrainian)

Malivskyi, A. M. (2018). Descartes about Anthropological Grounds of Philosophy in the "Early Writings". Anthropological Measurements of Philosophical Research, 14, 132-141. doi: https://doi.org/ 10.15802/ampr.v0i14.150769 (in English)

Ortega-y-Gasset, J. (1991). Chto takoe filosofiya? Moscow: Nauka. (in Russian)

Pascal, B. (2009). Dumky. Kyiv: Dukh i Litera. (in Ukrainian) 
Wienand, I. (2009). Discourses and Happiness. Ethical Perspectives, 16(1), 103-128. doi: https://doi.org/10.2143/ ep.16.1.2036280 (in English)

\section{LIST OF REFERENCE LINKS}

Ariew, R. Descartes and Pascal / R. Ariew // Perspectives on Science. - 2007. - Vol. 15, Iss. 4. - P. 397-409. doi: https://doi.org/10.1162/posc.2007.15.4.397

Descartes, R. Oeuvres Complètes : In 11 Vol. / R. Descartes. - Paris : C. Adam et P. Tannery, 1996. - 499 p.

Franchetti, C. The Giants of Doubt: A Comparison between Epistemological Aspects of Descartes and Pascal / C. Franchetti // Open Journal of Philosophy. - 2012. - Vol. 2, Iss. 3. - P. 183-188. doi: https://doi.org/ 10.4236/ojpp.2012.23028

The Cambridge Companion to Pascal / ed. N. Hammond. - Cambridge University Press, 2003. - 304 p. doi: https://doi.org/10.1017/ccol052180924x

Hibbs, T. Habits of the Heart: Pascal and the Ethics of Thought / T. Hibbs // International philosophical quarterly. 2005. - Vol. 45, Iss. 2. - P. 203-220. doi: https://doi.org/10.5840/ipq20054522

Хома, О. Декарт і Паскаль: шлях до філософії на тлі "Grand Siècle" / О. Хома // Філософська думка. - 2012. № 6. - С. 19-38.

Малівський, А. М. Антропологічний проект як підгрунтя картезіанської етики / А. М. Малівський // Антропологічні виміри філософських досліджень. - 2017. - Вип. 11. - С. 117-126. doi: https://doi.org/ 10.15802/ampr.v0i11.105495

Malivskyi, A. M. Descartes about Anthropological Grounds of Philosophy in the "Early Writings" / А. M. Malivskyi // Антропологічні виміри філософських досліджень. - 2018. - Вип. 14. - С. 132-141. doi: https://doi.org/10.15802/ampr.v0i14.150769

Ортега-и-Гассет, Х. Что такое философия? / Х. Ортега-и-Гассет. - Москва : Наука, 1991. - 408 с.

Паскаль, Б. Думки / Б. Паскаль. - Київ : Дух і Літера, 2009. - 704 с.

Wienand, I. Discourses and Happiness / I. Wienand // Ethical Perspectives. - 2009. - Vol. 16, Iss. 1. - P. 103-128. doi: https://doi.org/10.2143/ep.16.1.2036280

\section{А. М. МАЛІВСЬКИЙ ${ }^{1^{*}}$}

1* Дніпровський національний університет залізничного транспорту імені академіка В. Лазаряна (Дніпро, Україна), ел. пошта telepat-57@ukr.net, ORCID 0000-0002-6923-5145

\section{ВЧЕННЯ ПРО ЛЮДИНУ У ДЕКАРТА ТА ПАСКАЛЯ}

Мета. Аргументувати змістовну спорідненість позицій Декарта і Паскаля як двох варіантів відповіді на запит епохи щодо розбудови антропології. Реалізація означеної мети передбачає окреслення духовного клімату епохи та звертання до текстів двох великих французьких мислителів 17-го століття для демонстрації спільних моментів у тлумаченні феномену людини. Теоретичний базис. Методологічною основою дослідження є концептуальні положення представників феноменології та герменевтики. Наукова новизна. Аргументовано наявність вчення про людську природу в Декарта та окреслено прояви спільних моментів з вченням Паскаля. До числа чинників останніх належать контекст незавершеної революції Коперника, акцентування обмеженості методології природничих наук, інтенсивні шукання мови опису поза раціональних компонентів людської природи, висока оцінка християнського розуміння людини, критика атеїзму. Висновки. Обгрунтована змістовна спорідненість вчення про людину обох французьких мислителів, яка проявляється в баченні вихідної ситуації як вибору людиною власних засад в ході осмислення наукової революції, розумінні християнства як базової парадигми мислення, пріоритетності антропологічного інтересу над природничо-науковим, домінуюча роль етичного мотиву філософування.

Ключові слова: Декарт; Паскаль; людина; антропологія; релігія; раціональність; наукова революція; етика 


\author{
А. Н. МАЛИВСКИЙ ${ }^{*}$ \\ ${ }^{1 *}$ Днипровский национальный университет железнодорожного транспорта имени академика В. Лазаряна \\ (Днипро, Украина), эл. почта telepat-57@ukr.net, ORCID 0000-0002-6923-5145
}

\title{
КОНЦЕПЦИЯ ЧЕЛОВЕКА У ДЕКАРТА И ПАСКАЛЯ
}

Цель. Аргументировать содержательное родство антропологических позиций Декарта и Паскаля как двух вариантов ответа на запрос эпохи по развитию. Реализация указанной цели предусматривает определение духовного климата эпохи и обращение к текстам двух крупных французских мыслителей 17-го века для демонстрации общих моментов в толковании феномена человека. Теоретический базис. Методологической основой исследования являются концептуальные положения представителей феноменологии и герменевтики. Научная новизна. Аргументировано наличие учения о человеческой природе у Декарта и обозначены проявления общих моментов с учением Паскаля. К числу последних относятся контекст незавершенной революции Коперника, акцентирование ограниченности методологии естественных наук, интенсивные поиски языка описания внерациональных компонентов человеческой природы, высокая оценка христианского понимания человека, критика атеизма. Выводы. Обосновано содержательное родство учения о человеке обоих французских мыслителей, которое проявляется в видении исходной ситуации как выбора человеком собственных принципов в ходе осмысления научной революции, понимании христианства как базовой парадигмы мышления, приоритетности антропологического интереса над естественно-научным, доминирующая роль этического мотива философствования.

Ключевые слова: Декарт; Паскаль; человек; антропология; религия; рациональность; научная революция; этика

Received: 08.07.2019

Accepted: 21.11.2019 